\title{
As Reformas Religiosas na Europa Moderna notas para um debate historiográfico*
}

\section{The Religious Reformation in Modern Europe} notes for a historical debate

\author{
RODRIGO BENTES MONTEIRO \\ Doutor em História Social - Universidade de São Paulo \\ Departamento de História - Universidade Federal Fluminense \\ http://www.historia.uff.br/ciadasindias/ - rodbentes@terra.com.br
}

\begin{abstract}
RESUMO O artigo, como um verbete destinado aos cursos em História, pretende analisar a produção historiográfica, sobretudo européia, acerca das Reformas Religiosas no início da Europa Moderna. Evidencia a crítica de abordagens mais tradicionais adotadas por autores comprometidos com sua fé, e os estudos meramente institucionais, doutrinários ou funcionalistas. $O$ artigo destaca a atenção dada por historiadores do século XX ao contexto da "pré-reforma", à intensa devoção religiosa então vivida, e à conexão entre aspectos da vida religiosa, cultural, política e social da Europa Moderna.
\end{abstract}

Palavras-chave Reformas Religiosas, Europa Moderna, debate historiográfico

\footnotetext{
Artigo recebido em 10/01/2007. Aprovado em 15/04/2007.

(Esse artigo foi produzido originalmente como prova escrita realizada em concurso público na USP em 29/08/2000. Desde 2002, com meu ingresso no Departamento de História da UFF, foi divulgado entre alunos da graduação, e enriquecido com leituras referentes ao pós-doutorado sobre J ean Bodin e as guerras religiosas na USP, entre 2001 e 2002. Agradeço as sugestões bibliográficas feitas por Laura de Mello e Souza e as leituras críticas de Ronaldo Vainfas e Silvia Patuzzi, que levaram o texto à forma final. A Silvia Patuzzi dedico este artigo).
} 
ABSTRACT The article, as an introduction aimed to the course in History, intends to analyze the European historical production, related to the Religious Reformation in the Early Modern Europe. It focuses the more traditional approaches adopted by authors compromised with their own faith and on merely institutional, theological and functional studies. The article points to the attention given by the XXth Century historians, to the "pre-reformation" context, to the profound faith of the time, and to the connection of the religious, cultural, political and social aspects of life in Modern Europe.

Key words Religious Reformation, Modern Europe, historical debate

Os homens modernos não foram projetados no mundo, mas para dentro de si próprios. Hannah Arendt

No século XVIII, com o surgimento da filosofia da história em meio ao ambiente iluminista potencialmente revolucionário e anti-eclesiástico, 0 movimento conhecido como Reforma protestante era inserido no processo de modernização da sociedade ocidental, conforme as idéias de Hegel. Era a "mundanização positiva", diferente da conotação negativa atribuída pelo filósofo alemão ao contexto anterior da Escolástica. Enquanto estudiosos laicos entendiam a Reforma como fundação do caminho para a liberdade, católicos ultramontanos, defensores da infalibilidade papal, observavamna como um equívoco que desestabilizou princípios de autoridade, ordem social e disciplina, característicos da cristandade medieval. ${ }^{1}$

Na primeira metade dos Oitocentos, Leopold von Ranke inaugurou uma abordagem menos confessional e apologética, concomitante ao estabelecimento da História como disciplina e aos propósitos nacionais e políticos da Prússia após o Congresso de Viena, em 1815. No preâmbulo de sua história sobre os papas, as nações nórdicas e mediterrânicas ocultavam a tradicional dicotomia entre católicos e protestantes. Ranke queria enfatizar as relações entre setentrionais e meridionais, na passagem do século XV ao XVI. Mas, por trás de sua conhecida erudição no lidar com fatos militares, políticos e diplomáticos, subsistiam juízos de valor. Não obstante a aplicação do método de Barthold Niebuhr no estudo crítico das fontes, o jovem e fervoroso luterano centrou-se no período em que papado e império

1 Cf. MARRAMAO, Giacomo. Céu e Terra. Genealogia da secularização. São Paulo: Editora Unesp, 1997, p.26-30, primeira edição italiana de 1994. 
perdiam poder. Com a Reforma luterana, nascia a Idade Moderna, quando o "povo" tornava-se protagonista na história. Sua concepção de História Moderna não era assim forjada apenas por governantes e sacerdotes. Ela harmonizava-se também às necessidades do Estado prussiano, cuja política eclesiástica naquele momento dependia dos delicados matrimônios mistos entre protestantes e novos súditos católicos, cheios de soberba e inspirados nas tradições renanas. Também em sua obra maior sobre a história alemã na época da Reforma, Ranke mal disfarçou sua admiração por Lutero, embora afirmasse fazer uma história desapaixonada e imparcial do papado, pois a Roma católica já não ameaçava a nova e grande Prússia, fortalecida desde o século XVIII, até a unificação alemã em 1870-1871. Reprovava-se assim a Ranke a sua "malignidade protestante", bem como ter considerado a história da Igreja e da cristandade, mormente em seus aspectos político e institucional. ${ }^{2}$

Em 1906 o teólogo e filósofo Ernst Troeltsch - colega de Max Weber - apresentava seu livro sobre o protestantismo e o mundo moderno em um congresso de historiadores. Seu tema era a relação entre a herança religiosa do século XIV e a modernidade. Sem dogmatismo, o autor expôs a influência do protestantismo nas novas formas de sere de pensar do final do século XVIII. Troeltsch defendia que a religião protestante assemelhavase ao catolicismo medieval, em seu intento por restaurar a cultura religiosa antiga, com a novidade de enfatizar a liberdade individual. Embora tenha assinalado características próprias do luteranismo e do calvinismo, especialmente ante as autoridades políticas, o estudo de Troeltsch, na linha de uma teologia liberal, caracterizou-se por ser uma reflexão geral. ${ }^{3}$

\section{Fome de Deus}

Com efeito, o tema das Reformas Religiosas pertinente ao início da Época Moderna possui implicações que ultrapassam as mudanças institucionais eclesiásticas no século XVI, relacionando-se também a aspectos culturais, econômicos e de poder vividos na Europa. A historiografia nem sempre foi atenta a esses desdobramentos e relações, e pode-se afirmar que uma transformação significativa na análise das questões religiosas referentes ao século XVI começou a ocorrer a partir da década de trinta do século XX, com os trabalhos de Delio Cantimori, Lucien Febvre e Hubert J edin, até os anos cinqüenta. A explicação das novidades desta tríade de estudiosos e

2 RANKE, Leopold von. Historia de los Papas en la Época Modema. México: Fondo de Cultura Económica, 2004, p.13-67, primeira edição alemã em 1834-1836. Cf. CANTIMORI, Delio. Los Historiadores y la Historia. Barcelona: Península, 1985, p.127-148, primeira edição italiana de 1971. Sobre o estilo deste historiador, entre o "dramaturgo", o "cientista" e o "religioso", GAY, Peter. O Estilo na História. São Paulo: Companhia das Letras, p.63-93.

3 TROELTSCH, Ernst. El Protestantismo y el Mundo Modemo. México: Fondo de Cultura Económica, 2005. 
de seus respectivos desdobramentos, poderá esclarecer melhor o "antes" e o "depois" da produção historiográfica sobre as Reformas. ${ }^{4}$

Delio Cantimori é bastante conhecido por suas reflexões acerca dos problemas de periodização do Renascimento. Mas não somente. Em Umanesimo e Religione nel Rinascimento, o historiador italiano que propôs o termo Idade Humanística para a Época Moderna também procura relações entre o humanismo e a Reforma, concluindo que o protestantismo em seu advento representou o próprio fracasso do ideal humanista, da autoconfiança exacerbada no potencial do homem, otimismo excessivo em sua transformação através do livre arbítrio. Dessa forma, o servo arbítrio de Lutero seria não apenas o antídoto contra o livre arbítrio de Erasmo - princípio essencial à teologia católica -, mas a confirmação da onipotência divina em oposição ao programa educacional encetado pelos homens do Renascimento. Em Storici e Storia, grande obra do estudioso acerca da discussão historiográfica sobre Renascimento e Reforma, Cantimori coteja as interpretações realizadas sobre a Reforma protestante, desde o século XIX até meados do XX. Transparece assim a inovação do autor - também interessado em heterodoxias e heresias -, ao defender uma pesquisa mais argumentativa, que contemple a piedade e a sensibilidade religiosa, rompendo com controvérsias teológicas e eclesiásticas que caracterizavam muitos dos estudos. ${ }^{5}$

Lucien Febvre, como Delio Cantimori, não se particularizava por realizar uma história confessional - algo ainda relativamente novo entre estudiosos da Reforma - e como o italiano propunha também uma história da espiritualidade mais abrangente que as questões institucionais e teológicas vividas no século XVI, na Europa ocidental. No célebre estudo sobre os "problemas de conjunto", em Au Coeur Religieux du XVle Siècle, publicado postumamente, este historiador interroga-se sobre as origens da Reforma em França. Febvre refere-se ao problema dos historiadores franceses que, absorvidos pelas questões da "especificidade", da "prioridade" e da "nacionalidade", buscavam uma origem para a Reforma francesa em Lefèvre d'Étaples - um dos primeiros "pré-huguenotes" a realizar colóquios com Margarida de Valois, objeto de outro livro de Febvre -, em comparação a Lutero. Ao questionar, neste caso, a validade da história comparada, Lucien Febvre indica que o suposto primeiro reformador francês não criticava os abusos da Igreja, e que o problema do surgimento da Reforma deveria levar em conta a intensa religiosidade vivida na Europa - inclusive

4 Devo esta idéia sobre a tríade de historiadores a Silvia Patuzzi.

5 CANTIMORI, Los Historiadores e la Historia, op. cit., p.343-363, e Humanismo y Religiones en el Renacimiento. Barcelona: Península, 1984, p.151-171, edição original italiana de 1975. O interesse do historiador italiano pelas heterodoxias transparece em um estudo sobre hereges italianos no século XVI. CANTIMORI, Eretici Italiani del Cinquecento. Ricerche storiche. Firenze: Sansoni, 1939. Cf. também PATUZZI, Silvia. Humanistas, príncipes e reformadores no Renascimento. In: CAVALCANTE, Berenice (org.). Modemas Tradições. Percursos da cultura ocidental séculos XV-XVII. Rio de J aneiro: Access, 2002, p.85-175. 
na França - ao final do século XV e no início do século XVI: fidelidade às velhas crenças, devoção tradicional, a fé concretizada nos "testemunhos de pedra" do gótico tardio e no sucesso de obras surgidas no século XV, como a Imitação de Cristo, de Tomás de Kempis, que iria mais tarde conquistar a admiração de Erasmo de Rotterdam. Se a realidade devocional era forte, entre ela e o clero existia um abismo marcado pela insensibilidade. Deste modo, o historiador francês justifica o sucesso da Reforma - na França e alhures - mediante dois fatores: pelo surgimento da Bíblia em língua vulgar, e pela questão da justificativa da salvação pela fé. Em conclusivo, defende que a Reforma deve ser relacionada a uma crise moral e religiosa de muita gravidade que assolou a Europa naquele tempo. Para compreender este fenômeno, seria preciso pesquisar todas as manifestações diversas então vividas, na política, na economia, na sociedade, na cultura intelectual e artística. Portanto, para Febvre, os historiadores franceses atrapalhavamse, quando buscavam origens específicas em situações que eram gerais. A história da Reforma, segundo o historiador dos Annales, não poderia limitar-se em marcos institucionais, políticos e eclesiásticos. No entender de Cantimori, Febvre seria o "historiador psicólogo" atento, entretanto, às especificidades do homem do século XVI. ${ }^{6}$

Pode-se afirmar que J ean Delumeau desenvolveu e ampliou questões já estabelecidas por Lucien Febvre. Em Un Chemin d'Histoire, Chrétienté et Christianisation, Delumeau estuda os cristãos no tempo da Reforma e, também como Febvre, indaga-se sobre as causas do movimento protestante, mencionando a princípio duas explicações mais tradicionais: uma primeira que remete aos abusos da Igreja, e outra de cunho economicista, sobre a luta da burguesia contra o feudalismo. Delumeau argumenta que os protestos contra os abusos da Igreja não eram novidade, e que esta possibilidade explicativa não responde, por exemplo, ao fato de Erasmo, apesar de seus "protestos", ter continuado na Igreja católica, e nem à situação dos protestantes que não retornaram a ela quando o catolicismo se reformou. A explicação marxista, por sua vez, não esclarece a razão da Península Itálica, região próspera economicamente no início do século $\mathrm{XVI}$, ligada ao comércio mercantil, ter permanecido católica. 0 historiador francês indica as fragilidades existentes neste tipo de discussão, mais concentrada na difusão da Reforma que em suas causas, negligenciando também aspectos teológicos do debate. ${ }^{7}$

6 FEBVRE, Lucien. Problèmes d'ensemble, in Au Coeur Religieux du XVle Siècle. Paris: Le Livre de Poche Biblio Essais, 1983, p.7-95, publicação original de 1957. Cf. também Martí Luter. Barcelona: Empúries, 1984, primeira edição francesa de 1929 e Le Probleme de l'Incroyance au XVle Siècle. La religion de Rabelais. Paris: Albin Michel, 2003, primeira edição em 1942. Cf. também CANTIMORI, Los Historiadores y la Historia, op. cit., p.149-186.

7 DELUMEAU, J ean. Un Chemin d'Histoire, Chrétienté et Christianisation. Paris: Fayard, 1981, principalmente p.13153. Cf. também A Civilização do Renascimento. Lisboa: Estampa, 1994, v.1, p.121-147, primeira edição francesa de 1964. São muitas as obras do historiador sobre o tema, impossíveis de serem citadas neste artigo. 
A seguir Delumeau - como já o fizera Lucien Febvre - detém-se na análise dos comportamentos religiosos na Europa do início do século XVI. Em resumo, ele verifica a existência de um cristianismo popular mais íntimo e profundo, cristianismo vivido de forma plena - em seu aspecto formal - somente pelas elites. Tratava-se então de um mundo de ignorância religiosa, distante dos abusos da Igreja. 0 historiador refere-se, como exemplo, ao livro de Keith Thomas, Religion and the Dec line of Magic, que retrata a sociedade inglesa do século XVI repleta de práticas mágicas e crenças, relacionadas pelo autor aos mecanismos de solidariedade aldeã, em contraposição à afirmação da propriedade privada e do individualismo. Processo no qual o(a) outro(a), o(a) estranho(a), o(a) diferente, tendia a ser acusado(a) de feitiçaria pelos vizinhos. Delumeau também - repetind o Febvre - refere-se ao sucesso de Imitação de Cristo, obra que resume o ideal de devotamento, pobreza e piedade na Europa de então. Era um mundo também de medo - retomando um dos mais conhecidos temas do historiador abordado em La Peur en Occident, tão bem expresso pelo holandês J ohan Huizinga, já em 1919, no seu Herfsttij der Middeleeuwen, literalmente Outono da Idade Média. Peste, fome e guerra estavam relacionadas ao pânico, e à superstição como solução para os problemas. O combate à superstição constitui outro tema desenvolvido por Delumeau, luta importante efetuada por Lutero e Calvino. Tentando analisar os escritos dos reformadores como material etnológico, o historiador francês concebe a Reforma como promoção da vontade cristianizadora, contra o catolicismo, mas também contra a idolatria, vilões não distintos para eles. ${ }^{8}$

A realidade conflituosa e mesclada em termos religiosos, recuperada por Delumeau, deve alertar os estudiosos do período sobre a imprudência que podem demonstrar ao tentar separar, sempre, o que é religioso do que é mágico. São muitos os exemplos procedentes em relação a esta questão: o estudo de Emmanuel Le Roy Ladurie, Montaillou, village occitan de 1294 à 1324, demonstra que, já no final da Idade Média, cristão e religioso não eram sinônimos. Em Le Carnaval de Romans. De la chandeleur au mercredi des cendres 1579-1580, sobre os festejos realizados naquela cidade francesa, que misturavam aspectos religiosos e profanos, Ladurie verifica a mesma dificuldade de classificação, bem percebida por Natalie Davis na coletânea de ensaios intitulada Society and Culture in Early Modern France, sobre a Reforma e os grupos sociais populares franceses no século XVI. 0 exemplo mais conhecido talvez seja o estudado por Carlo Ginzburg - discípulo de Cantimori em sua atenção às heresias e à micro-história - em II

8 DELUMEAU, J ean. Un Chemin d'Histoire, Chrétienté et Christianisation. Referências a THOMAS, Keith. Religião e Declínio da Magia. São Paulo: Companhia das Letras, 1991, edição inglesa de 1971. DELUMEAU, J ean. História do Medo no Ocidente 1300-1800. Uma cidade sitiada. São Paulo: Companhia das Letras, 1989, primeira edição francesa de 1978. HUIZINGA, J ohan. O Declínio da Idade Média. São Paulo: Edusp, 1984, tradução de versão condensada em inglês. 
Formaggio e i Vermi. Il cosmo di un mugnaio del '500. Na cosmologia toda especial de Menocchio, percebe-se não somente a circularidade cultural, mas a dificuldade de tipificação do que seria a boa religião, aceita pelos inquisidores. O moleiro era batizado e se confessava e, no entanto, foi considerado blasfemador e herege pela Igreja. O livro de Ginzburg chama atenção para a possibilidade de diferentes leituras sociais e culturais do cristianismo. Em conclusivo, na obra há pouco referida, J ean Delumeau concebe a marcha do cristianismo como progressiva e não triunfal dentro da cristandade, sublinhando o equívoco perigoso para os historiadores que lidam somente com os aspectos institucionais da filiação religiosa. ${ }^{9}$

A consideração de outra obra do mesmo historiador, Le Catholicisme entre Luther et Voltaire, indica o caminho para a abordagem da Reforma católica, e para o modo como o referido autor concebe as reformas: como atos não seqüenciais entre si, tentando entender sua gênese para além da tradicional questão em torno dos abusos da Igreja. Neste livro, Delumeau argumenta que a renovação da Igreja se deu em dois momentos, o da préreforma e o iniciado no Concílio de Trento (1545-1563), quando os prelados ali reunidos atenderam alguns pleitos de J oão Huss, Bernardo de Siena e Savonarola. $O$ autor também chama atenção para o ambiente de solidez teológica da Espanha no século XVI, onde surgiu a vocação religiosa de Inácio de Loyola e o neotomismo da Universidade de Salamanca. Em relação ao Concílio de Trento, Delumeau desenvolve seu estudo em torno de uma questão: como um evento que contou com tantas dificuldades, que foi iniciado com tanto ceticismo e com tão pouco expressivo número de clérigos, como este acontecimento que enfrentou obstáculos por parte de soberanos europeus como Francisco I, e que precisava tanto do apoio dos chefes de Estado católicos, como pôde este evento marcar de tal forma a história da Igreja. Delumeau responde a esta questão defendend o que a grandeza do Concílio de Trento consistiu em atender às necessidades religiosas de seu tempo, tal como a Reforma protestante. Estabelece um paralelo entre o Édito de Nantes (1598) e este concílio, pois os dois acontecimentos efetivamente realizaram o que os anteriores decretos de tolerância - no caso do primeiro - e as anteriores reformas, no segundo, não concretizaram, permanecendo letra morta. Segundo o autor, a cristandade ocidental, em meados do sé-

9 DELUMEAU, J ean. Un Chemin d'Histoire, Chrétienté et Christianisation. LADURIE, Emmanuel Le Roy. Montaillou. Cátaros e católicos numa aldeia francesa 1294-1324. Lisboa: Edições 70, s.d., primeira edição francesa de 1975 e DELUMEAU, J ean. $O$ Carnaval de Romans. Da candelária à quarta-feira de cinzas - 1579-1580. São Paulo: Companhia das Letras, 2002, edição francesa de 1979. DAVIS, Natalie Zemon. Culturas do Povo. Sociedade e cultura no início da França modema. Rio de J aneiro: Paz e Terra, 1990, edição norte-americana de 1975. GINZBURG, Carlo. 0 Queijo e os Vermes. O cotidiano e as idéias de um moleiro perseguido pela Inquisição. São Paulo: Companhia das Letras, 1987, edição italiana de 1976; GINZBURG, Carlo. Os Andarilhos do Bem. Feitiçarias e cultos agrários nos séculos XVI e XVII. São Paulo: Companhia das Letras, 1990, primeira edição de 1966 e GINZBURG, Carlo. História Notuma. Decifrando o sabá. São Paulo: Companhia das Letras, 1991, primeira edição de 1989. Na linha da micro-história também se Destaca LEVI, Giovanni. A Herança Imaterial. Trajetória de um exorcista no Piemonte do século XVII. Rio de J aneiro: Civilização Brasileira, 2000, primeira edição em 1985. 
culo XVI, vivia uma mutação profunda, tinha "fome de Deus". Esta fome se manifestava, por um lado, pela busca da palavra da vida, mas também pelo pânico dos pecados. A saciedade desta fome pode ser percebida, após o Concílio, pelo comportamento mais moralizado de alguns papas, pela renovação de Roma enquanto capital religiosa, pelos sínodos, seminários e visitas pastorais intensificados, e pelas novas ordens religiosas criadas. Algumas ordens, como a dos capuchinhos e das ursulinas, precederam 0 próprio Concílio, impressionando a sensibilidade religiosa da época. O utras se destacaram pela pujança de suas realizações, como foi o caso notório dos jesuítas, soldados de Cristo que abrangeram o além-mar, e dos carmelitas descalços liderados por Teresa d'Ávila, renovando o catolicismo na Espanha de Felipe II. Deste modo, nesta obra, o autor propõe duas leituras da Reforma católica: uma sobre o endurecimento das estruturas, com um clero mais firme e com ênfase na catequese; e outra, a falar de santidade e piedade, de exemplos heróicos testemunhados nas vidas de papas e religiosos do século XVI. ${ }^{10}$

Torna-se oportuno, assim, em se tratando de Reforma católica, recuperar um nome apenas mencionado ao início como componente de uma tríade fundamental para o entendimento das inovações historiográficas sobre a Reforma. Coube a Hubert J edin, jesuíta alemão que conseguiu o acesso aos documentos do Concílio de Trento, a criação do conceito de Reforma católica, diferente de Contra-Reforma. Em sua história sobre o Concílio de Trento, J edin renova os estudos da estrutura organizacional da Igreja no século XVI, contemplando também o período da pré-reforma, o que possibilita pensar as mudanças vividas no papado durante os Quinhentos. 0 autor alemão enfatiza as linhas de força do Concílio, caracterizadas pelo reforço das escrituras e da tradição, seguindo passo a passo a marcha do evento, analisando a diplomacia entre Roma, Trento e Salamanca, e a influência das idéias erasmianas. J ed in é mencionado por J ean Delumeau como o melhor historiador da Reforma católica. ${ }^{11}$

Contudo, a Reforma católica, como já foi indicado, não pode ser restrita ou tipificada apenas pelas decisões conciliares. J ohn Bossy, em Christianity in the West 1400-1700, fornece-nos o interessante exemplo de uma reforma silenciosa, caracterizada pela investida dos clérigos em disciplinar as práticas do casamento - em oposição às fiançailles, que consumavam a união antes do laço institucional definitivo -; do batizado logo após o nascimento; da confissão periódica. Nesses casos, tratava-se de promover a passagem de uma cristandade medieval para um moderno catolicismo,

10 DELUMEAU. Le Catholicisme entre Luther et Voltaire. Paris: PUF, 1994, primeira edição em 1971.

11 JEDIN, Hubert. História del Concilio de Trento. Pamplona: Ediciones Universidad de Navarra, 1972, tradução castelhana do original alemão Geschichte des Konzils von Trient, de 1957, e o artigo Catholic Reformation or Counter-Reformation? In: LUEBKE, David M. (org.). The Counter-Reformation. Malden/ Oxford: Blackwell Publishing, 1999, p.19-46. 
mediante rompimento dos vínculos de uma solidariedade grupal para uma delegação de responsabilidades ao indivíduo como católico. ${ }^{12} \mathrm{~A}$ Reforma católica em Portugal tem sido trabalhada por Federico Palomo com ênfase neste catolicismo moderno. Retomaremos essa questão tão importante sobre a "modernidade" das Reformas Religiosas ao final do artigo. ${ }^{13}$

Deve-se ainda mencionar, para que se tenha noção de um quadro mais rico e complexo acerca do universo religioso no século XVI - não necessariamente polarizado entre protestantismo e catolicismo -, a existência de outras correntes de pensamento não tão engajadas em disputas. 0 historiador italiano Alberto Tenenti desenvolveu um já clássico estudo sobre 0 libertinismo, publicado nos Annales, no qual se faz evidente - mais uma vez - a dificuldade de classificação sobre o que seria herético ou ortodoxo em termos religiosos. Não obstante, 0 autor indica três tipos de libertinismo entre a metade do século XVI e o início do século XVII. Um libertinismo espiritual, mais relacionado aos místicos medievais; o demonstrado por J ean Bodin, em seu Heptaplomeres, que Tenenti relaciona a um tempo futuro, o das Luzes; e aquele praticado por Pierre Charron, este sim, segundo o autor, mais identificado ao seu tempo. Posteriormente, o libertinismo foi estudado por Sergio Bertelli, em Rebeldes, Libertinos y Ortodoxos en El Barroco. Este historiador italiano organizaria ainda o colóquio II Libertinismo in Europa, que resultou em obra também publicada. ${ }^{14}$

O quadro complexo, referente ao universo religioso e cultural na Europa do início da Época Moderna, também deveria englobar outros movimentos, dentro do próprio contexto de pré-reforma no século XV, como o evangelismo e, posteriormente, no século XVII, o jansenismo. ${ }^{15}$ Também seria importante aprofundar o entendimento do papel fundamental desempenhado pela eloqüência e pela retórica na Reforma católica, em especial na obra dos jesuítas, tema desenvolvido por Marc Fumaroli, em L'Âge d'Éloquence. ${ }^{16}$

12 BOSSY, J ohn. A Cristandade no Ocidente 1400-1700. Lisboa: Edições 70, 1990, primeira edição inglesa em 1985 e 0 artigo BOSSY, J ohn. The Counter-Reformation and the people of catholic Europe. In: LUEBKE. (org.). The Counter-Reformation, p.85-104.

13 PALOMO, Federico. Fazer dos Campos Escolas Excelentes. Os jesuítas de Évora e as missões do interior em Portugal 1551-1630. Lisboa: Fundação Calouste Gulbenkian, 2003, e PALOMO, Federico. A Contra-Reforma em Portugal 1540-1700. Lisboa: Livros Horizonte, 2006.

14 TENENTI, Alberto. Libertinisme et hérésie milieu du 16e siècle, début du 17e siècle. Annales - ESC - Hérésies et Societés, ano 18, no 1, p.1-19, jan-fev. de 1963. Cf. também MAGNARD, Pierre. Le Colloquium Heptaplomeres et la religión de la raison. In ZARKA, Yves Charles (org.). J ean Bodin Nature, Histoire, Droit et Politique. Paris: Presses Universitaires de France, 1996, p.3-22 e MONTEIRO, Rodrigo Bentes. A república de J ean Bodin: uma interpretação do universo político francês durante as guerras de religião. Tempo. Revista do Departamento de História da UFF. Rio de J aneiro: 7 Letras, v.18, no 15, p.161-177, jul. 2003. BERTELLI, Sergio. Rebeldes, Libertinos y Ortodoxos en el Barroco. Barcelona: Península, 1984, primeira edição italiana em 1973 e BERTELLI (org.). II Libertinismo in Europa. Milano / Napole: Riccardo Ricciardi Editore, 1980.

15 Para uma ótima síntese sobre o jansenismo SOUZA, Evergton Sales. J ansénisme et Reforme de L'Église dans L' Empire Portugais 1640 à 1790. Paris: Centre Culturel Calouste Gulbenkian, 2004, p.33-91.

16 FUMAROLI, Marc. L'Âge de L'Éloquence. Réthorique et res literaria de la Renaissance au seuil de l'époque classique. Paris: Albin Michel, 1994. 


\section{Secularização desencantada}

Mas para se buscar coerência em relação ao sugerido, sobre a indistinção na Europa de início da Época Moderna entre múltiplos aspectos componentes daquele mundo e o tema das Reformas Religiosas, alguns estudos complementam 0 argumento proposto.

$\mathrm{Na}$ segunda metade do século XX, enquanto estudiosos marxistas identificavam na figura de Thomas Münter um líder revolucionário em meio às guerras camponesas no século $\mathrm{XVI},{ }^{17}$ a historiografia revisionista esforçava-se por atacar modelos teóricos de interpretação. Em ensaio bastante divulgado, Hugh Trevor-Roper dialoga com a conhecida tese de Max Weber sobre a ética protestante e o espírito do capitalismo. Após investigar trajetórias e comportamentos de empresários calvinistas neerlandeses, soberanos católicos e protestantes, em meio à Guerra dos Trinta Anos (1618-1648) que assolou a Europa, o historiador inglês conclui sobre a existência de um vínculo indireto entre calvinismo e capitalismo na Europa ocidental - e não direto, como advogavam interpretações marxistas e weberianas, ainda que de modos muito distintos. Em síntese, Trevor-Roper constata uma conversão generalizada de empresários "capitalistas" erasmianos (simpatizantes de Erasmo), perseguidos pela Igreja de Roma e desfavorecidos pelas cortes católicas, para o calvinismo. Esta conversão teria sido acompanhada de uma migração dos mesmos de países católicos para repúblicas protestantes, por conta do avanço da burocracia estatal das cortes européias, que sufocava o capitalismo independente dos simpatizantes de Erasmo. Portanto, segundo o autor, não seria propriamente o catolicismo a impedir diretamente o capitalismo nas cidades do sul do Sacro Império, das Penínsulas Ibérica e Itálica, pois nessas regiões já existiria um "capitalismo medieval" feito por católicos - termo excêntrico empregado por Roper. Nessa perspectiva seria imprópria a idéia weberiana acerca da ética calvinista como principal motor, de forma direta, do desenvolvimento capitalista. Talvez a tendência conservadora do autor na política inglesa ajude a entender a redução excessiva que ele opera em relação ao peso das causas e ideologias nas transformações sociais. Pinta, assim, um quadro de meras disputas por oportunidades e conveniências ao hiperdimensionar o avanço das cortes absolutistas como sistemas de poder. Mas é evidente em sua análise o valor da pesquisa histórica em contraposição a modelos sociológicos generalizantes. Não obstante também transparece de modo diferente de outras análises economicistas, a relação entre a vida econômica e social e a religião. ${ }^{18}$

17 O exemplo mais conhecido é o livro de BLOCH, Ernst. Thomas Müntzer, teólogo da revolução. Rio de J aneiro: Tempo Brasileiro, 1973, primeira edição de 1962.

18 TREVOR-ROPER, Hugh. Religião Reforma e Transformação Social. Lisboa: Presença, 1972, p.13-42, primeira edição em 1969. WEBER, Max. A Ética Protestante e o Espírito do Capitalismo. São Paulo: Pioneira, 1983, edição original alemã de 1905. 
A menção crítica à sociologia de Weber abre espaço para considerar a incidência de suas idéias nos estudos históricos sobre a Reforma e o alvorecer da Idade Moderna, sobretudo no que se refere à categoria de secularização. Segundo o filósofo Giacomo Marramo, o termo secularizar surgiu ao final do século XVI nas disputas canônicas francesas, relacionado à passagem de um religioso regular ao estado secular. Foi empregado também nas longas negociações em Münster, 1646, para a Paz de Vestfália em 1648, sobre a transferência de propriedades religiosas para mãos seculares. 0 neologismo indicava a expropriação de bens eclesiásticos a favor de príncipes ou igrejas reformadas. Desde as lutas pela Reforma, o termo relacionava-se à afirmação de uma jurisdição secular - ou estatal - sobre setores da vida social até então sob domínio da lgreja. ${ }^{19}$

Como sabemos pelo trabalho de Reinhart Koselleck, em meados do século XVIII era forjado o conceito de progresso na forma que nos é familiar, com uma prospectiva futurizante. Nesse tempo a secularização aparecia ligada ao conceito unitário de tempo histórico. Surgia assim a idéia do progresso como temporalidade cumulativa e irreversível, a representar o moderno processo de secularização. ${ }^{20} 0$ tempo como mudança e transformação constante tornava-se assim a forma por excelência da modernidade. No século XIX, a palavra secularização conheceu uma extensão semântica, primeiro no campo político, com a expropriação dos domínios religiosos pelo decreto napoleônico, de 1803, posteriormente na sociologia.

Com efeito, o desenvolvimento da moderna sociedade européia ocidental foi pensado pela primeira vez, de forma completa, por Max Weber, no início do século XX, como "processo de secularização". Por um lado, a expressão remetia a uma concepção geral do processo cultural no Ocidente; mas por outro, a concepção deste mesmo processo rompeu com as filosofias da História anteriores, na versão idealista de Hegel, ou na materialista de Marx. Para Marramao, o papel da secularização em Weber seria incompreensível sem a tese da ética do protestantismo calvinista como base do espírito do capitalismo, aspecto do crescente "racionalismo ocidental moderno". Contudo, a amplitude do panorama não caracteriza uma filosofia da História na obra weberiana. As categorias de Weber foram extraídas de uma seleção empírica e comparativa que identificou traços peculiares no interior de expressões genéricas como "capitalismo" ou "racionalismo ocidental". Para explicar esse processo, Weber fez referência a condições econômicas, científicas e jurídicas, mas também à capacidade e à disposição dos agentes sociais para adotarem condutas racionais de vida. Nesta

19 Para essas reflexões MARRAMAO. Poder e Secularização. As categorias do tempo. São Paulo: Editora UNESP, 1995, primeira edição italiana de 1983 e MARRAMAO. Céu e Terra.

20 KOSELLECK, Reinhart. Crítica e Crise. Uma contribuição à patogênese do mundo burguês. Rio de J aneiro: Eduerj, 1999, primeira edição alemã de 1959 e KOSELLECK, Reinhart. Futuro Passado. Contribuição à semântica dos tempos históricos. Rio de J aneiro: Contraponto/Editora PUC-Rio, 2006, primeira edição alemã de 1979. 
via, evidenciou o fator ético do agir que, identificado na ascese característica da Reforma, conectava-se à problemática da secularização. ${ }^{21}$

Para Weber, o aspecto decisivo da secularização ligava-se à prevalência de um modo de agir racional, que encontrou sua expressão na ética da renúncia e da ascese no protestantismo calvinista puritano. Mediante a doutrina da graça e sua ratificação manifesta nas obras e no sucesso, a atitude protestante daria lugar a um rigor religioso, mas também a uma aderência ao mundo que - constituindo o espírito do capitalismo - induziria nas relações sociais um forte efeito de dessacralização. Em Die Protestantische Ethik un der Geits des Kapitalismus, a secularização enquadrava-se nesse processo de desencantamento do mundo, traduzindo-se numa recusa dos meios mágicos e sacramentais de busca da salvação. 0 tópico foi esclarecido em Wirtschaft und Gesellschaft, obra póstuma na qual o sociólogo separou as figuras do profeta e do sacerdote pela vocação pessoal. Essa separação foi decisiva para captar a dimensão dessacralizante do profetismo, como manancial da dinâmica secularizante. Se o sacerdote era legitimado pelo cargo, o profeta atuava em virtude dos seus dons pessoais. Pela amplitude de perspectiva e riqueza de conteúdo, a sociologia religiosa de Weber representou um divisor de águas nos estudos sobre a secularização. ${ }^{22}$

Mas a grandeza da descoberta de Weber sobre as origens do capitalismo encontra-se em demonstrar que uma intensa atividade mundana era possível sem se desfrutar do mundo excessivamente, apenas na valorização do trabalho, uma atividade cuja motivação, ao contrário, era a preocupação e interesse de cada um por si próprio. Segundo Marramao, a alienação do mundo, portanto, e não a alienação de si, como pensava Marx, seria a característica distintiva da Idade Moderna. Entretanto, a tese weberiana exerceu influência sob o signo do processo de "desencantamento do mundo". 0 poder sugestivo desta fórmula marcou a discussão sobre a secularização da sociedade moderna. ${ }^{23}$

Nesse sentido, para Marramao, a tese da dessacralização foi precipitadamente atribuída ao sociólogo alemão. Em Weber, a análise da secularização excluiu qualquer sentimento ou juízo de valor ameaçador da eficácia do processo. Ele perseguiu o nexo entre secularização e racionalização, como um destino histórico irreversível. Mas seu "desencantamento" não comportaria um mundo desideologizado e dessacralizado. Faz-se evidente assim a inconsistência do esquema sacro-profano para exprimir a complexidade da categoria de secularização.

21 MARRAMAO, Poder e Secularização e MARRAMAO, Céu e Terra.

22 WEBER. A Ética Protestante e o Espírito do Capitalismo; e WEBER. Economia y Sociedad. Esbozo de sociología comprensiva. México: Fondo de Cultura Económica, 2002, p.328-492, primeira edição em 1922.

23 MARRAMAO. Poder e Secularização; e MARRAMAO. Céu e Terra. 
Marramao observa o problema desta ampliação de sentidos ocorrida com a palavra, pois secularização acabou figurando como uma filosofia da história camuflada, um termo indeterminado e controverso, interpretado como descristianização ou dessacralização. No âmbito político, utilizado para tratar da perda de modelos tradicionais de valor e de autoridade, fenômeno que, a partir da Reforma protestante, consistiu na ruptura do monopólio da interpretação. Já no debate filosófico figura como sinônimo da erosão dos fundamentos teológicos e da abertura à dimensão da escolha, da responsabilidade e do agir do homem no mundo. Para o filósofo italiano é necessário distinguir entre esses dois paradigmas: o da secularização, do moderno como mundanização de um núcleo original meta-humano; e o da laicização, ou libertação, ou seja, do moderno como desimpedimento do indivíduo em sua progressiva auto-afirmação.

É curioso perceber que os fenômenos da expropriação de bens e da alienação do mundo, na construção de uma identidade mais individualizada, coincidiram no tempo. A Idade Moderna começou por alienar do mundo certos extratos da população. Tendemos a negligenciar a importância desta alienação, porque sublinhamos seu caráter secular, e identificamos a secularização também à reconquista do mundo. No entanto, historicamente a secularização apenas significou a separação entre Igreja e Estado, religião e política. De um ponto de vista político, parece um retorno à máxima cristã "dar a César o que é de César e a Deus o que é de Deus" e não o desaparecimento da fé na transcendência, ou um interesse enfático pelas coisas do mundo. Portanto, a suposta perda da fé na Idade Moderna não pode ser relacionada às Reformas Religiosas. Lutero substituiu a religiosidade exterior pela interior, a fé na autoridade pela autoridade da fé.

\section{Religião política}

Entretanto, são muitos os exemplos de interação entre religião e política, no início da Época Moderna, em Cortes reformadas ou católicas, que relativizam a separação entre Igreja e Estado no campo institucional ou nas idéias relativas ao governo e à moral. Para Marc Bloch, no célebre Les Rois Thaumaturges, publicado em 1924, o absolutismo era uma espécie de religião. Sob a influência da Sociologia de Durkheim, Bloch estuda os rituais de cura de escrófulas, a unção régia e o leque de legendas que envolvia as monarquias na Inglaterra e na França, desde tempos medievais. 0 historiador francês deixa evidente a simbiose existente entre a realeza e 0 sagrado, que perdurou na Corte inglesa até a ascensão da dinastia Hanover, e na França até a Revolução, com uma revivência efêmera na coroação de Carlos X, em 1825. Por sua vez, Ernst Kantorowicz, inspirado na teologia política de Carl Schmitt, estuda em dois capítulos inciais de The King's Two Bodies a elaboração dos juristas da era Tudor em torno da ficção dos dois 
corpos do rei inglês: quanto ao primeiro, sujeito a paixões e morte como qualquer outro homem, mas quanto ao segundo, imortal e sagrado, idéia também presente nas peças de Shakespeare. 0 tema seria retomado por Ralph Giesey, discípulo de Kantorowicz, ao estudar os funerais dos reis franceses nos séculos XV e XVI, em Le Roi ne MeurtJ amais, e por Agostino Bagliani, ao sublinhar as diferenças em relação ao funeral papal. ${ }^{24}$

No âmbito das idéias políticas, Quentin Skinner concede atenção em The Fundations of Modern Political Thought às idéias de Erasmo e outros humanistas, bem como a luteranos e calvinistas e suas concepções no século XVI. Embora a Sociologia de Weber seja referencial na sua interpretação do "moderno", o historiador de Cambridge contempla um universo vasto de textos, muitos deles medíocres, de forma a estabelecero "contexto intertextual" e posicionar melhor obras consideradas seminais do pensamento político moderno. Destaca-se o estudo sobre a mudança da política protestante: da consideração do príncipe como predestinado por Deus, ao dever de resisitir e lutar pela deposição de um tirano, mormente em Cortes católicas, como Escócia e França. 0 universo neotomista também é contemplado no ambiente da Reforma católica e do caráter contratual vigente nas monarquias ibéricas. ${ }^{25}$

Em perspectiva diferente de Skinner, pela maior especificação das situações políticas, encontram-se os estudos dos irmãos Firpo. Luigi Firpo é autor de uma introdução primorosa a uma edição italiana de 0 lamento pela paz, texto de Erasmo feito para o encontro em Cambrai, 1516, reunindo 0 imperador, os reis de França e da Ing laterra. 0 historiador italiano ressalta a influência do contexto do ducado da Borgonha e suas possessões - entre elas Rotterdam - no pensamento de Erasmo pela paz e por uma monarquia universal. Após narrar os episódios que culminaram na derrota borgonhesa em Nancy, Firpo interpreta o "lamento" de Erasmo como melancolia pelo ocaso de uma civilização perdida - a da Borgonha -, que buscava, pela diplomacia, algum melhor tratamento entre soberanos mais poderosos. Por sua vez, Massimo Firpo escreve sobre os homens do clero no artigo intitulado $O$ cardeal, na obra organizada por Eugénio Garin acerca do homem renascentista. Ante o quadro comumente aceito para pintar o vértice da Igreja em Roma, no início do século XVI, de violência, devassidão, avidez e corrupção, o autor observa que, naquele tempo, nada disso provocava

24 BLOCH, Marc. Os Reis Taumaturgos. O caráter sobrenatural do poder régio França e Inglaterra. São Paulo: Companhia das Letras, 1993, sobretudo p.215-249. KANTOROWICZ, Ernst H. Os Dois Corpos do Rei. Um estudo de teologia política medieval. São Paulo: Companhia das Letras, 1998, p.21-47, primeira edição de Princeton, em 1957. GIESEY, Ralph. Le Roi ne Meurt J amais. Les obsèques royales dans la France de la Renaissance. Paris: Flammarion, 1987. BAGLIANI, Agostino Paravicini. Le Corps du Pape. Paris: Seuil, 1997, edição italiana de 1994 Sobre esta discussão historiográfica MONTEIRO. Crítica monumental. Tempo, v. 10, n. 19, p.201-205, 2005.

25 SKINNER, Quentin. As Fundações do Pensamento Político Moderno. São Paulo: Companhia das Letras, 1996, primeira edição inglesa de 1978. Em perspectiva mais filosófica, uma abordagem da missionação na América foi empreendida pelo italiano IMBRUGLIA, Girolamo. L'invenzione del Paraguay. Studio sull'idea di comunità tra Seicento e Settecento. Napoli: Bibliopolis, 1983. 
escândalo, pois a consciência comum não separava clérigos e leigos. Uma imagem austera e contrita da vida religiosa só seria afirmada no contexto posterior da Reforma católica. Firpo evita assim as avaliações moralistas sobre a mundanidade da hierarquia eclesiástica entre os séculos XV e XVI, e 0 anacronismo das interpretações. ${ }^{26}$

Particularizando o âmbito católico, os estudos inquisitoriais têm sido altamente renovados em Roma, para o caso itálico, com a recente abertura do Archivio della Congregazione per la Dottrina della Fede, do extinto Santo Ofício, projeto que compreende em sua comissão Massimo Firpo, Carlo Ginzburg e Adriano Prosperi, entre outros. Neste setor também destacamse os estudos ibéricos, pela riqueza dos arquivos existentes. Em síntese, a farta bibliografia sobre inquisição espanhola pode ser tipificada em duas vertentes principais: os estudos de historiadores espanhóis sobre tribunais, capitaneados porJ aime Contreras, e uma linha socio-cultural exemplificada pelos livros de Bartolomé Benassar. Trata-se de uma historiografia mais concentrada nos resumos dos processos. No meio portuguuês, destacam-se os trabalhos de Francisco Bethencourt, que produziu uma visão de conjunto sobre a dinâmica inquisitorial em Portugal, Espanha e Itália. A superação de uma abordagem mais institucional tem sido empreendida por J osé Pedro Paiva, seja pela contemplação da fetiçaria lusa, seja pelo instigante capítulo que assina na História Religiosa de Portugal, no qual versa sobre a interpenetração entre Igreja e Estado no Portugal do Antigo Regime. ${ }^{27}$

Entretanto, pode-se explicitar com mais vagar um caso de vínculos estreitos entre as Reformas Religiosas e as questões políticas, desfazendo fronteiras entre religião, magia, filosofia, e o próprio exercício do poder. Ao enveredar pelo ambiente intelectual da monarquia francesa no tempo das Guerras de Religião (1559-1598), Denis Crouzet identifica, após a eclosão dos conflitos, duas respostas da realeza - não excludentes entre si - às violências interconfessionais. A mais evidente, de matriz humanista, tentava fundar a paz pela tolerância da fé reformada. Provavelmente de fonte erasmiana, foi dominante de 1560 a 1568, liderada pelo chanceler Michel de L'Hôspital, que se esforçou com alguns intelectuais - os politiques, entre eles J ean Bodin - para tornar política uma visão da ordem régia. Além dos

26 FIRPO, Luigi (org.). Erasmo de Rotterdam. II Lamentto della Pace. Milano: Tea, 1997, p.5-29. FIRPO, Massimo, 0 cardeal. In: GARIN, Eugénio (org.). 0 Homem Renascentista. Lisboa: Presença, 1991, primeira edição italiana de 1988, p.59-97.

27 CONTRERAS, Jaime. Historia de la Inquisición Española (1478-1834). Madrid: Arco Libros, 1997. BENASSAR, Bartolomé. Inquisición Española. Poder político y control social. Barcelona: Grijalbo, 1984. BETHENCOURT, Francisco. História das Inquisições. Portugal, Espanha e Itália séculos XV-XIX. São Paulo: Companhia das Letras, 2000, primeira edição de 1995. PAIVA, J osé Pedro. Bruxaria e Superstição num País sem "Caça às Bruxas" (1600-1774). Lisboa: Notícias, 1997 e PAIVA, J osé Pedro. A Igreja e o poder. In: AZEVEDO, Carlos Moreira (dir.). MARQUES, J oão Francisco \& GOUVEIA, António Camões (org.). História Religiosa de Portugal. Humanismo e Reformas. Lisboa: Círculo de Leitores, 2000, v.2, p.135-185. Uma abordagem que mescla aspectos devocionais, corporações de ofício e ação inquisitorial faz-se presente no livro de SANTOS, Georgina Silva dos. Ofício e Sangue. A Irmandade de São J orge e a Inquisição na Lisboa Moderna. Lisboa: Colibri, 2005. 
ódios, existia a solução da tolerância como preservação do Estado, pois sem um poder dominante, os homens guerreariam ao infinito. 0 rei devia manter a paz, justificativa da organização social e política capaz de findar os conflitos. ${ }^{28}$

Mas havia outra corrente filosófica que convém enfatizar. No século XVI, diálogos de Platão eram lidos nas academias italianas, sobretudo em Florença, onde conferências sobre a filosofia do amor eram freqüentes. Obras de Platão e dos antigos platônicos, além das atribuídas a Orfeu, Zoroastro, Hermes e aos pitagóricos, eram editadas em grego e latim. Os escritos platônicos renascentistas também foram difundidos em línguas vernáculas, sobretudo francesa e italiana. Na França, doutos como Lefèvre d'Etaples e poetas religiosos como Margarida de Valois valiam-se das idéias de Marsílio Ficino, no seu apelo à contemplação e à experiência interior. O amor platônico tornava-se então uma moda nas academias literárias. A influência do platonismo também ocorria na matemática apreciada por Platão e seus seguidores, a expressar a superioridade do conhecimento quantitativo sobre o qualitativo, da matemática sobre a física, do platonismo sobre 0 aristotelismo.

Nesse âmbito, segundo Crouzet, o poder régio francês da Renascença se caracterizava pela capacidade do rei governar como um iniciado nos segredos do universo. No sistema neoplatônico de Ronsard, poeta da corte, o universo era regido por uma lei de alternância. Mesmo que o dia seguisse a noite, que as estações se sucedessem, o bom tempo viria após a tempestade. Em 1566, um teórico definia o príncipe como aquele que devia, por suas virtudes, ser sábio para guiar o povo aos bons modos, na crença e no amor de Deus. As festas da Corte no tempo de Catarina de Médici e de seus filhos podiam chocar pela suntuosidade. Mas a diversão civilizada afirmava a virtude pacificadora do príncipe que vivia em tranqüilidade, oferecendo prazeres e diferenciando-se do tirano, que proporcionava opressão, angústias, medos. As festas eram então espelhos da justiça e piedade régias, incluindo os presentes na consagração das virtudes, reflexos da beleza universal cuja sabedoria só o príncipe possuía. Nesse sentido, festas, quadros, túmulos e poesias organizados na corte Valois atuavam como talismãs, inspirados em teorias neoplatônicas e herméticas.

A educação principesca, através de Plutarco, visava fazer de Carlos IX um rei filósofo à semelhança dos descritos na República de Platão. Como a força unificadora do mundo era um fogo, a chama da realeza por meio da educação e da ciência devia ser mantida acesa, contra a degenerescência.

28 Para essas informações, CROUZET, Denis. La Nuit de la Saint-Barthélemy. Un rêve perdu de la Renaissance. Paris: Fayard, 1994. Cf. também MONTEIRO \& RAMUNDO, Walter Marcelo. O estado de Bodin no estado do homem renascentista. Revista de História. Departamento de História da Universidade de São Paulo, São Paulo: Humanitas, no 152, p.189-214, 2005. 
Rei filósofo e mago que se ocupava das ciências da natureza e agia no plano natural. Contra a violência, uma realeza da harmonia dos contrários se impunha. Os problemas da França eram naturalizados assim pela lógica da instabilidade das coisas humanas, da bonança ao sofrimento, e vice-versa. A harmonia universal era esse movimento pendular incessante, cabendo aos governantes promover a concórdia.

Nesse mundo religioso dilacerado, o amor neoplatônico era a última defesa contra a ruptura, tentativa de adesão da monarquia ao movimento universal, a esta sabedoria ou prudência que afastava os efeitos astrais, superando os desafios políticos e religiosos, pela harmonia de contrários que assegurava a perpetuação da vida. 0 homem era, portanto, ambivalente, definindo-se numa dualidade conservadora das coisas. Os que detinham o poder político deviam atuar segundo essa compensação para atingir o equilíbrio. Catarina de Médici, nos libelos huguenotes, após o massacre de 1572, tornou-se uma feiticeira, responsável pelos males da França. De fato, ela pertencia a uma cultura mágica. Na Renascença, poder significava também atração de forças, comunhão com o fluxo vital, parte de um sistema esotérico de conhecimento que condicionava a política. Além dos eventos das guerras de religião, existia uma cultura que aglutinava poder monárquico, neoplatonismo e hermetismo, ou seja, realeza, filosofia e magia. A "religião" dos últimos Valois era então diferente das confrontantes, catolicismo e protestantismo, ao fazer da arte política uma arte mística. Denis Crouzet defende a busca do poder na França, da segunda metade do século XVI, nas imagens do mundo que seus contemporâneos compunham, em função dos seus sistemas filosófico-metafísicos.

Ao conceber o poder como discurso, o historiador francês explica o massacre de 24 de agosto de 1572 como um sonho perdido da Renascença, e alivia o drama da violência religiosa na França do século XVI, que recebeu outra abordagem, por exemplo, de Natalie Davis. No ensaio, intitulado Ritos de violência, a historiadora de tendência etnográfica recupera cenas cotidianas que opunham católicos e protestantes, demonstrando que os massacres não podem ser explicados apenas pelas ordens vindas de cima, nem pela alta dos preços, nem como loucura coletiva. Segundo Davis, a religião era vivida de forma violenta por vários segmentos sociais. Deste modo a autora recupera o tema da devoção religiosa, e aproxima sua análise das anteriores inovações de Febvre e Delumeau, ao rejeitar explicações puramente economicistas ou institucionais. ${ }^{29}$

Não obstante a leveza dos conflitos inerentes às guerras religiosas no ensaio de Crouzet, ele desenvolve versões acerca do evento e da família real, católicas e protestantes, que Ihe permitem trabalhar a construção de

29 DAVIS. Ritos de violência, in Culturas do Povo, p.129-156. 
estereótipos políticos de personagens como Catarina de Médici e Carlos IX: a rainha feiticeira, o rei caçador. Entretanto, o ponto central para a argumentação proposta neste artigo surge ao se buscar a ponte com a idéia lançada por Delio Cantimori, sobre a Reforma como "fracasso" do humanismo. ${ }^{30}$ Denis Crouzet aborda o massacre de 24 de agosto de 1572 como um sonho perdido da Renascença, um ideal neoplatônico de amor e tolerância religiosa - expresso nas formações intelectuais e de governo incidentes em membros da família real dos Valois Angoulême. Sonho destruído pela estratégia do malfadado assassínio do almirante Gaspar de Coligny - na época influente sobre o rei Carlos -, pelo acuamento político da família régia ante os radicais protestantes, e pela falência da tolerância religiosa promovida pela monarquia. Esse conjunto resultaria no plano do massacre, polêmico no referente à extensão da ordem do rei, se dirigida aos chefes protestantes, ou a todos os huguenotes em Paris. De qualquer modo, a fúria coletiva foi desencadeada em todo o reino, mediante oposições religiosas que eram ao mesmo tempo políticas. ${ }^{31}$

\section{Reforma moderna}

Atento às relações entre linguagem e história, Koselleck observa que - ao menos no espaço alemão -, somente nos Setecentos começou-se a tratar dos "tempos modernos", o termo implantando-se lexicalmente no século XIX. Assim, o conceito de modernidade impôs-se séculos após o início do período que pretendia abarcar - o século XVI. Como sabemos, a expressão relaciona-se à criação do conceito de Idade Média. 0 recurso dos humanistas ao modelo da Antiguidade limitava o ínterim bárbaro em um período, e conduzia Petrarca, no século XIV, ao primeiro uso histórico do medium tempus. Embora o termo tenha ingressado nos círculos eruditos, a Idade Média como perío do despontou apenas no século XVIII, solidificandose no XIX. Como o seu par moderno. ${ }^{32}$

30 CANTIMORI. Humanismo y Religiones en el Renacimiento.

31 CROUZET, Denis. La Nuit de la Saint-Barthélemy.

32 A expressão tempos modemos significa o novo, o atual em oposição ao passado. Mas também uma tensão qualitativa, melhor em relação ao anterior. Nesse caso indica novas experiências, adquirindo assim uma característica de época. Também se refere retroativamente a um período que se concebia como novo frente à Idade Média. Koselleck observa que entre os séculos XIV e XVII, os anais e crônicas continuaram sendo escritos de forma a fixarem acontecimentos sucessivos. Como a escrita medieval, as histórias eram redigidas desde os respectivos "começos" - do mundo, de uma cidade etc. - ao longo do tempo. Histórias baseadas em testemunhos e exemplos, de autoridade indiscutida. Os novos acontecimentos eram incluídos nessas histórias, sem que se lhes reconhecesse o caráter de fundação de um novo tempo. Nessa historiografia aditiva, as periodizações não remetiam à novidade do tempo no qual elas mesmas se encontravam. A passagem da menção a um tempo próprio, presente, para a conotação de tempos modernos, seria indicativa para saber quando se descobriu a história do tempo próprio como nova. Este processo teria surgido no século XVII, consumando-se lentamente. Para determinar o próprio tempo como moderno em oposição ao passado, e por extensão à história antiga, era preciso uma postura diferente ante o passado, mas também em relação ao futuro. Somente depois que a expectativa cristã no fim do mundo perdeu seu caráter de contínuo presente, pôde-se descobrir um tempo ilimitado e aberto ao novo. Essa virada em direção ao futuro consumou-se, sobretudo, após as guerras religiosas, que esgotaram as expectativas cristãs. Para essas reflexões KOSELLECK, Futuro Passado, p.267-303. 
Com efeito, Idade Média e Idade Moderna encontram-se entrelaçadas a Renascimento e Reforma. Mas, enquanto a idéia do Renascimento em oposição aos tempos medievais necessitou de tempo até consolidar-se como um período nos Oitocentos, a palavra Reforma no âmbito protestante ganhou rapidamente um sentido, evoluindo depois para a concepção de um período específico. Inicialmente apresentava um significado não cronológico, referindo-se à vida religiosa, ao ordenamento da Igreja ou ao direito tradicional. Posteriormente, a historiografia protestante singularizou a expressão como um conceito de época - a Reforma de Lutero e seus companheiros, vinculada à restauração da pureza da mensagem da sagrada escritura, inaugurando o último perío do cristão.

Entretanto, a remissão ao ensaio de Delio Cantimori encaminha melhor a reflexão final do artigo, sobre as Reformas Religiosas como tópico característico da Época Moderna. Lembrando ainda as idéias do historiador italiano, percebe-se a aproximação feita por ele entre os dois movimentos culturais, Humanismo e Reforma: pelo espírito crítico presente em ambos, e pelo conhecimento do idioma a fim de se conhecer a verdade no lidar com os textos antigos - os provenientes de autores clássicos, ou a Bíblia traduzida e interpretada. Cantimori também enfatiza o autoconhecimento como aspecto fundamental aos humanistas autores de tratados de educação, bem como aos reformadores protestantes e seus adeptos. Em sua digressão, identifica diferentes gerações de humanistas, desde o otimismo de Ficino e Mirandola na oração que dignificava o homem, até o realismo moralista de Erasmo ou o pessimismo racional de Maquiavel, a observarem a mesma natureza humana de modos diferentes. Não obstante, humanistas e reformadores concediam a ela grande atenção. A passagem do tempo do Humanismo ao tempo da Reforma, da grandeza do homem a sua pequenez perante Deus, teria seu marco simbólico no saque de Roma em 1527, quando tropas de Carlos V mostraram à Península Itálica a impotência daquela civilização brilhante. No dispersar dos humanistas, solapava-se o entusiasmo restaurador de uma idade do ouro, que cedia lugar às controvérsias doutrinais, e ao espírito teológico dos reformadores. Desse modo, no original ensaio do historiador italiano, a Reforma protestante manifestou-se historicamente como inimiga do Humanismo. Não por acaso, alguns humanistas italianos e franceses posicionaram-se a favor da Reforma católica, mais simpática à idéia de livre-arbítrio. ${ }^{33}$

Contudo, será preciso recuperar um elemento comum aos dois movimentos - Reformas Religiosas e Humanismo -, e situá-lo no contexto tratado. Ele se encontra na negativa da oposição entre os conceitos laico e religioso. Vimos como Giacomo Marramao sublinhou o despertar da consciência

33 CANTIMORI. Humanismo y Religiones en el Renacimiento. 
individual, presente na Reforma, como gérmen da modernidade ocidental, no âmbito filosófico que destaca a laicização como libertação do homem em relação às instâncias universais. Por sua vez, Hannah Arendt disserta sobre um limiar da Idade Moderna, que consistiria em três grandes eventos, entre eles a Reforma protestante. Por meio da estatização de bens eclesiásticos, o movimento reformador desencadearia o duplo processo de exp ropriação e de acumulação de riqueza social. Mas Arendt também identifica um traço da modernidade no fenômeno religioso da alienação do mundo que, sob o nome de ascetismo mundano, Weber identificou como origem da nova mentalidade capitalista. Para Arendt, longe de contradizerem-se, as duas tendências - a expropriação e a alienação do mundo - coincidem. A secularização não implica o desaparecimento da fé ou um novo interesse pelas coisas deste mundo. Consequentemente, o perfil do homem moderno não seria dado pela mundanidade, mas pela sua interioridade. ${ }^{34}$

Não obstante as descontinuidades entre linguagem e história para a conceituação de uma Época Moderna desde o século XVI - já apontadas por Koselleck -, verifica-se o surgimento da questão da individualidade em meio ao contexto das Reformas Religiosas. Uma consciência mais individual encontra-se contemplada no incentivo ao conhecimento de si mesmo apregoado por Lutero e Calvino. Mas também na ação católica de maior vigilância sobre os fiéis, exemplificada pelos trabalhos de Hubert J edin e J ohn Bossy. Processo concomitante à construção de identidades próprias mediante a constatação das diferenças alheias, algo tão característico do homem moderno - ou renascentista, na acepção de Garin -, evidente na dimensão antropológica dos trabalhos de Carlo Ginzburg, entre outros. ${ }^{35}$ Portanto, parece apropriada a acepção das Reformas Religiosas como elementos de uma modernidade germinal, não obstante as permanências vigentes nos séculos XVI, XVII e XVIII.

$O$ debate apresentado, ao eleger como objeto principal as Reformas Religiosas na Europa ocidental durante o século XVI, mostrou a consideração do mundo popular, devocional e mágico, além das questões puramente institucionais e teológicas, ou exclusivamente econômicas, em relação a outros aspectos do mundo moderno. Tal quadro era composto por uma realidade plural e multifacetada, destacada no âmbito religioso. Ao priorizar trabalhos historiográficos de meados do século XX, o artigo também cotejou a incidência de certos modelos de interpretação nos estudos históricos, e a discussão sobre a "modernidade" pertinente ao tema. No presente, novos objetos de pesquisa, recortes conceituais e abordagens possibilitam pensar

34 MARRAMAO. Poder e Secularização;. e MARRAMAO. Céu e Terra; ARENDT, Hannah. A Condição Humana. Rio de J aneiro: Forense Universitária, 2003, editado primeiramente em 1958.

35 KOSELLECK. Futuro Passado; J EDIN. História del Concilio de Trento; BOSSY. A Cristandade no Ocidente 1400 1700; GARIN, Eugénio (org.). O Homem Renascentista, p.9-16 e GARIN, Eugénio. Idade Média e Renascimento. Lisboa: Estampa, 1989, p.83-96, primeira edição de 1988. GINZBURG, O Queijo e os Vermes. 
as Reformas Religiosas com um distanciamento que Cantimori, Febvre e J edin, por exemplo, não puderam vivenciar. As hagiografias, o culto aos santos, o messianismo e os sermões, as festas e a vida paroquial, as visitas inquisitoriais como percepção da comunidade, a mestiçagem cultural e as histórias de grupos eclesiásticos representam algumas dessas perspectivas temáticas, dos temas e abordagens encontrados em vários trabalhos acerca do universo colonizador nas Américas espanhola e portuguesa, alguns deles inspirados em autores citados no decorrer deste texto. Mas esta já seria uma outra história, certamente objeto para outro artigo. 